\title{
The Scope of Immunity for Legislators and
}

\section{Their Employees}

The Constitution provides that "for any Speech or Debate in either House, [the Senators and Representatives] shall not be questioned in any other Place." 1 The literal wording of the clause suggests an absolute legislative immunity limited to words spoken in the actual chambers of Congress. ${ }^{2}$ But the courts have not inclined to such a purely verbal test so limited in locus; instead, they have interpreted the guaranty to include much more than verbal expression. Despite occasional loose talk of an absolute immunity for anything done or said during the congressional session, ${ }^{3}$ however, the reach of the Clause has never been entirely clear. Recent decisions of the Supreme Court have generated a renewed uncertainty, and suggest that the Justices may be about to narrow substantially the scope of the legislative privilege. ${ }^{4}$

I.

The Supreme Court first passed on the meaning of the Speech or Debate Clause in 1880. Kilboum v. Thompson ${ }^{5}$ was a suit for false imprisonment, brought against the Sergeant at Arms of the House and

1. U.S. Const. art. I, \& 6.

2. Cf. Methodist Fed'n for Social Action v. Eastland, 141 F. Supp. 729, 734 (D.D.C. 1956) (dissenting opinion). The limited nature of the Clause becomes apparcut by comparison to the other immunity granted in the same sentence of Section 6:

They shall in all Cases, except Treason, Felony and Breach of the Peace, be privileged from Arrest during their Attendance at the Session of their respective Houses, and in going to and returning from the same; and for any Speech or Debate in either House, they shall not be questioned in any other Place.

The privilege from arrest in "all" cases other than those exceptcd contrasts sharply with the "in either House" language of the speech or debate privilege.

The Founding Fathers did not discuss the Speech or Debate Clause at the Constitu. tional Convention. The wording of the Clause comes nearly verbatim from the andlo. gous provision in the Articles of Confederation, art. $V$, which in turn derived from an act of Parliament adopted following the Glorious Revolution. 1 W. \& M., 2d Sers., c. 2 art. 9 (1688). For the English history, see Note, The Bribed Congressman's Immunity from Prosecution, 75 YALE L.J. 335, 336-39 (1965).

3. E.g., Yellin v. United States, 374 U.S. 109, 122 (1963) (dictum); Barsky v. Inited States, 167 F.2d 241, 250 (D.C. Cir. 1948), cert. denied, 334 U.S. 843 (1948); Lusk v. IIanrahan, 244 F. Supp. 539, 540 (E.D. Ill. 1965) (dictum); Keogh v. Pearson, 244 F. Supp. 482. 486 (D.D.C. 1965) (dictum); cf. Powell v. McCormack, 266 F. Supp. 354, 355 (D.D.C. 1967) (dictum).

4. Dombrowski v. Eastland, 387 U.S. 82 (1967); United States v. Johnson, 383 U.S. 169 (1966)

5. 103 U.S. 168 (1881). 
certain representatives, after the congressmen had the Sergeant confine the plaintiff to the District of Columbia jail for refusing to answer committee questions about the collapse of the Jay Cooke Company. ${ }^{\circ}$ The Court permitted the action against the Sergeant at Arms, but held that the Clause immunized the legislators; ${ }^{7}$ it dismissed as unduly "narrow" the view of the provision that would "limit it to words spoken in debate,"8 and quoted approvingly from the landmark English decision in Stockdale v. Hansard, ${ }^{9}$ where the Queen's Bench had conferred an immunity on members of Parliament for "whatever is done within the halls of [the] assembly. . . ."10 It also quoted from the Massachusetts case of Coffin v. Coffin ${ }^{11}$ - which the Court termed "the most authoritative in this country"12 - where Chief Judge Parsons had extended the state constitutional immunity to "every thing said or done by [the member] as a representative, in the exercise of the functions of that office, without inquiring whether the exercise was regular according to the rules of the house, or irregular and against their rules."13

Despite the approving citations, however, the Kilbourn Court did not adopt the broad and unqualified language of either Slockdale or Coffin. Instead, the justices decided only that the Clause protected the activities challenged in the case before them: committee reports,

6. The committee, composed of five representatives, reported Kilbourn's refusal to answer the questions, whereupon the House found him in contempt and ordered his incarceration. Id. at 174-75.

7. All the defendants argued that Congress had the povier to order the arrest for contempt, and that all persons contributing to or effectuating that order viere therefore immune as a consequence of the power itself. The congressmen added that they were discharging their duties as members of the House and were therefore immune on grounds of legislative privilege. Id. at 177-79. The Court's holding that Congress lacked the power to order the arrest left Thompson without a defense, apparently on the theory that the immunity shielded "members" only. Id. at 200; see p. 373 infra.

8. 103 U.S. at 204.

9. 9 A. \& E. I, 112 Eng. Rep. 1112 (Q.B. 1839).

10. Id. at 114, 112 Eng. Rep. at 1156. Stockdale held that the parliamentary immunity did not extend to the private printer of the debates to protect him in a libel suit brought for words of a member. The decision was overturned by statute, $3 \& 4$ Vict., c. $9(1840)$.

The Kilbourn Court suggested that the Speech or Debate Clause codified the laws of England, including the rule in Stockdale, 103 U.S. at 202; but the explanation is questionable, given that Stockdale itself was decided some fifty jears after the adoption of the Constitution.

11. 4 Miass. 1 (1808)

12. 103 U.S. at 204 .

13. 4 Mass. at 27. Despite the breadth of its language, the Massachusetts Supreme Judicial Court held that the privilege did not protect a member from civil suit when the alleged slander was made in a casual remark in the chamber. The decision came in the teeth of the Massachusetts Constitution, providing that "[t]he freedom of delibera. tion, speech and debate in either house of the legislature is so essential to the rights of the people, that it cannot be the foundation of any accusation or prosccution, action or complaint, in any other court or place whatsoever." Miass. Const. art. XXII. 
resolutions offered in the chamber, and voting, whether done vocally or through tellers. ${ }^{14}$ If this comprised the holding of the case, as in a technical sense it did, Kilbourn might stand for a quite narrow interpretation of the Clause, conferring an immunity only for essential legislative activities carried out within the literal walls of Congress.

But Mr. Justice Miller went on to state, "In short, [the immunity embraces] things generally done in a session of the House by one of its members in relation to the business before it."15 Whether this was intended as a shorthand summary of what had gone before or as a new general definition for the scope of immunity, the Court left unclear. If its statement stood as holding, it suggested, in essence, an objective "scope of legislative employment" test for a legislative immunity transcending the literal wording of the Clause: a member could claim protection for any of the sort of "things generally done in a session," provided it had some pertinency "to the business before [the legislature]."

No matter how broadly or narrowly it intended to define the immunity, however, in the next paragraph of its opinion the Kilbourn Court staked out a right to hold legislators legally responsible for "things done ... of an extraordinary character," comparable, for example, to the Long Parliament's "execution of the Chief Magistrate" or to the French Assembly's "assuming the function of a court for capital punishment." "[W]e are not prepared to say," wrote Mr. Justice Miller, "that such an utter perversion of [the congressmen's] powers to a criminal purpose would be screened from punishment by the constitutional provision for freedom of debate."10 The reservation of a judicial prerogative to inquire into the subjective "criminal purpose" of the legislator, coupled with the casual appearance of a definition for the Clause which may or may not have been intended by the Court as a general statement of the immunity's scope, signaled a significant withdrawal from the sweeping grants of privilege issued in Stockdale and Coffin.

Seventy years later, the Supreme Court again dealt with the Clause. In Tenney $v$. Brandhove, ${ }^{17}$ the plaintiff brought a civil rights suit against the members of the California Senate Fact-Finding Committee on Un-American Activities under Section 1983,18 alleging that de-

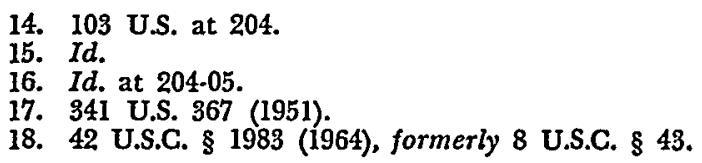


fendants had coerced and intimidated him in his exercise of first amendment rights by summoning him to appear before them and then ordering him prosecuted for contempt when he refused to answer their questions. The Court, through Mr. Justice Frankfurter, denied that the term "any person" in Section 1983 included a state legislator acting within the scope of his authority; the 1871 Congress that passed the Givil Rights Act would not, given an already centuryold privilege, have curtailed the immunity so drastically by recourse to such general language. ${ }^{19}$ The "immunity" invoked by the Court was apparently of a general common-law character, unattached to any specific constitutional provisions, state or federal. ${ }^{20}$ Still, Tenney purported to follow Kilbourn's test, asking whether the legislators were acting "within the sphere of legitimate legislative activity." Justice Frankfurter then brought legislative investigations conclusively within the sphere, ${ }^{22}$ contrary to Kilbourn dicta on the subject, ${ }^{23}$ and limited judicial supervision to cases where it was "obvious that there [had been] . . . a usurpation of functions exclusively vested in the Judiciary or Executive."24 The Tenney Court also omitted Kilbourn's pertinency requirement, and, most significantly, it expressly denied a judicial power to inquire into a legislator's motive, stating that " $[t]$ he claim of an unworthy purpose does not destroy the privilege."25

\section{341 U.S. at 376.}

20. The Tenney opinion seemed to draw on a common-law tradition thought to illuminate, if not survive, state and federal constitutional enactments. Even before the English Bill of Rights of 1688, an incipient common-linw immunity from liability for civil injury had taken clear form as the judiciary recognized that the benefits from compensating victims and deterring official excesses did not outweigh the socinl loss in inhibiting courageous, independent parliamentary action and in deterring persons espousing novel and therefore radical ideas from entering public service. Sec 1 F. Harper \& F. JAMiEs, The LAw of TORTS 428 (1956); 2 id. 1641. As the parliamentary struggle with the monarchy developed in the sisteenth and seventcenth oenturies, it beame clear that the immunity from civil suit shielding the speech of legislators did not provide a parallel defense against criminal prosecution by the Crown. Stockdale v. Fansard, 9 A. \&. E. 1, 113-14, 112 Eng. Rep. 1112,1156 (Q.B. 1839). In his hejday, the King regularly prosecuted critical members of Parliament for seditious libel, a crime loosely defined as any criticism of the government. See, e.g., Rex v. Tutchin, 14 St. Tr. 1095 (1704). reported sub nom. Tuchin's Case, Holt, K.B. 423, 90 Eng. Rep. 1133 (K.B. n.d.). When Parliament gained the upper hand in 1688, it demanded and received from the Crown a Bill of Rights which, although it did not eliminate all avenues of monarchical repression, contained a free-speech-and-debate clause good against both private suit and public prosecution. I W. \& M., 2d Sess. c. 2, art. 9 (1688); 6 W. Holdswortr, History of Evicusi LAw 231 (2d ed. 1936). See generally C. WITtKe, The Histori of Eiglsil ParLasiestary Privilege (1921).

21. 341 U.S. at 376.
22. Id. at $377-78$.

23. 103 U.S. at 196-97.

24. 341 U.S. at 378.

25. Id. at 377. The impropriety of judicial inquiry into the motives of legislators has its roots in the doctrine of separation of powers; it dates from the case of Fletcher $v$. Peck, 10 U.S. (6 Cranch) 87 (1810), where the Court refused to inquire into the motives 
Tenney's impact on Kilbourn depended largely on what one made of Kilbourn in the first place. If that decision did no more than tack committee reports and voting to speech and debate, and if the talk about scrutiny of motive was limited to congressional behendings of the Chief Executive, then Tenney effectively did nothing more than add committee investigating to the existing roster of absolutely protected activities. But if Kilbourn limited an objective scope-of-employment test by the threat of judicial inquiry into personal intent, then Tenney represented a severe cutback of judicial review to legislative "usurpations," and a correspondingly significant expansion of legislative privilege.

Aside from Kilbourn and Tenney, three lower court decisions between 1930 and 1960 in District of Columbia defamation suits gave the only further content to the Clause until 1966. In Cochran $v$. Couzens, ${ }^{26}$ the court of appeals granted the defendant senator an absolute immunity from a slander action where the complaint showed his words were "uttered in the course of a speech ... in the chamber of the Senate," even though they were unrelated to any business then before the body. ${ }^{27}$ Apparently, where the defendant's utterance satisfied the literal language of the Clause itself, the Kilbourn suggestion of a pertinency requirement would not apply. ${ }^{28}$ In Long $v$. Ansell, ${ }^{20}$ a libel action based on reprints of a Senate speech taken from the Congressional Record and mailed to the defendant senator's home state, Judge Van Orsdel remarked in dictum that a defense under the Clause "would be without force, since the acts charged have only a remote connection with the speech. While the published articles were in part reproductions of the speech, the offense consists not in what

of the Georgia legislature, allegedly bribed nearly to a man to enact the Yazoo land grant. See C. MCGRATH, YAzOo (1966). In Fletcher the Court decided that the validity of a legislative act does not depend on the motives of its many members; practically speaking, it would be impossible for the judges to conduct the necessary investigations. For the possible limitation of the Fletcher rule to Congress, see Baker v. Carr, 369 U.S. 186 (1962).

But deference to formal enactments of even a co-equal branch of govetnment does not dictate similar respect for the acts of a single legislator. The teasons for congressional immunity do not demand that the Court refuse to examine motives in its quest for the proper limits of the Speech or Debate Clause. See Note, The Bribed Congressman's Immunity from Prosecution, 75 YALE L.J. 335, 340 (1965). Despite the special factors apparent in the Fletcher situation, subsequent courts have failed to differentiate acts of Congress and those of one of its members. United States v. Johnson, 383 U.S. 169, 180 (1966); Tenney v. Brandhove, 341 U.S. 367, 377 (1951).

26. 42 F.2d 783 (D.C. Cir. 1930).

27. Id. at 784 .

28. Cochran was willing to remit the plaintiff to the uncertain remedy of a disciplititary action against the senator by his peers. See U.S. ConsT. art. I, \$ 5, cl. 2; $42 \mathrm{~F} .2 \mathrm{~d}$ at 78.1 . 29. 69 F.2d 386 (D.C. Cir. 1934). 
was said in the Senate, but in the publication and circularizing of the libelous documents." 30 The distinction between speech and publication was not an appealing one, especially given the constitutional mandate requiring the printing of the Congressional Record; ${ }^{31}$ and unless the Public Printer were to be personally liable for all he set in type, the Long dictum would have to differentiate initial publication in the Record from subsequent reprinting by the senator. Such a distinction would make sense only on a restrictive, literalist reading of the Clause that limited the privilege as closely as possible to words actually spoken in Congress, but not on a more expansive, scope-ofemployment interpretation. It was, however, precisely the line subsequently drawn by Judge Youngdahl in McGovern $v$. Martz, ${ }^{32}$ nine years after Tenney. There the congressman brought an action for defamation, and the defendant counterclaimed for a libel appearing in the Congressional Record appendix and in various republications. In a narrow construction of the Clause, the court extended an absolute immunity to the printed appendix, but only a qualified immunity to the reprints; the purpose the court attributed to the legislative privilege- "complete and uninhibited discussion among legislators"33 - simply did not apply to a republication for constituents. ${ }^{34}$

In 1966 the Supreme Court offered its third reading of the Clause. United States $v$. Johnson ${ }^{35}$ was a criminal prosecution of a former representative for conflict of interest and conspiracy to defraud the United States. ${ }^{36}$ The Government's evidence included a speech the defendant had made on the floor of the House. The Court held the speech inadmissible in a prosecution under general criminal statutes, ${ }^{37}$

\footnotetext{
30. Id. at 389 .

31. U.S. CONST., art. I, § 5, cl. 3.

32. 182 F. Supp. 343 (1960).

39. Id. at 347 (emphasis in original).

34. The discussion of republication was dictum. On a broader view of the immunity; the court would have had to explain why the Clause should protect intralcgislative communication but not a congressman's statements to his electorate. On either theory the court might well have indicated why, if the reason for the privilege applied only to the former case, the legislator should enjoy eren a qualified immunity in the latter.

For another, peripherally relevant District of Columbia decision, cf. Arcthodist Fcd'n for Social Action v. Eastland, 141 F. Supp. 729 (D.D.C. 1950) (suit to cnjoin publication of Internal Security Subcommittee booklet terming plaintiff a Communist-Iront organization, and suit to declare resolution ordering printing unconstitutional, held dismissed for want or jurisdiction as to senator and for failure to state a cause of action as to Public Printer).

35. 383 U.S. 169 (1966).

36. 18 U.S.C. $\S \S 281$ (conflict of interest), 37 (fraud) (1964).

37. 383 U.S. at 180. The Clause would not protect the legislator, said the Court, where the prosecution involved no "legislative acts ... [nor the defendant's] motives for performing them" nor did the Court pass on the ase where "a prosecution, though possibly entailing inquiry into legislative acts or motivations, is founded upon a narrovily
} 
and remanded for retrial. The congressman's remarks had gone in to show improper motive, and that, said Mr. Justice Harlan, "is precisely what the Speech or Debate Clause generally forecloses from executive and judicial inquiry." 38 The statement all but demolished the restrictive reading of Kilbourn, which would protect legislators only from direct prosecution for activities on the floor of Congress, since such a narrow interpretation of the Clause arguably would not prohibit the use of a speech merely as background evidence in a prosecution for a substantive offense committed outside the House-here, lobbying before the Justice Department to win dismissal of charges against constituents. ${ }^{39}$

But a tacit withdrawal from a strict construction of Kilbourn did not leave the Court with an objective scope-of-employment formulation. The intimation that the Clause might not always foreclose inquiry into motive suddenly ripened into precisely the consideration of improper purpose that Tenney had held impermissible:

No argument is made, nor do we think that it could be successfully contended, that the ... Clause reaches conduct, such as wats involved in the attempt to influence the Department of Justice, that is in no wise related to the due functioning of the legislative process. $^{40}$

Now, representations before administrative agencies are as much a part of the legislative function, and therefore within an objective scope-ofemployment test for the immunity, as voting and making speeches. ${ }^{41}$ Perhaps Harlan was saying that an attempt to win dismissal of an indictment from the Justice Department is per se beyond the "due functioning of the legislative process," no matter what the motives of the suppliant Congressman. But that is an unlikely reading of the passage, given the number of occasions where, for one good-faith political reason or another, a representative might consider dismissal of charges against third parties a wise move for the Justice Department to make. The Court's seemingly cavalier attitude toward any possible claim of immunity under the Speech or Debate Glause was more

drawn statute passed by Congress in the exercise of its legislative power to regulate the conduct of its members." $I d$. at 185.

38. Id. at 180 (emphasis added).

39. Id. at 172 .

40. Id.

41. Cf. May v. United States, 175 F.2d 994, 1006 (D.C. Gir. 1949), (Congressman who received compensation for his services before an agency was guilty of an illegal act cven though he acted "within the scope of his official duties as a Congressman' Bribed Congressman's Immunity from Prosecution, 75 YALE L.J. 335, 336, 316 (1965). 
intelligible if the Justices were attaching a pejorative connotation to the word "influence": not any intercession, but an intercession with improper motive would receive no protection under the Clause. But if this was the case, the effect of the "influence" language was to abandon Tenney's professions of judicial refusal to assess motive and to move back toward the original Kilbourn assertion that the judges might inquire into "criminal purpose," even while the Court insisted it was following the test laid down in Tenney.

After Johnson, then, the results of the cases appeared more consistent than the reasons used to arrive at them. Congressmen enjoyed an absolute immunity for speeches, votes, and reports in the chamber, as well as for committee investigating wherever held, but only a qualified privilege for other customary legislative activity beyond the walls of the Houses and for republications of their hitherto immune speeches.

The status of immunity for legislative employees was considerably less certain. Kilbourn in its disposition of the action against the various defendants had suggested, although it did not hold, that the constitutional provision applied only to "members." 42 Tenney obfuscated matters with an off-hand observation that the "[l]egislative privilege ... deserves greater respect [where congressmen are involved] than where an official acting on behalf of the legislature is sued"13 - a passage leaving it unclear whether the employee shared to some extent or other in the congressman's constitutional immunity, ${ }^{14}$ or whether his only protection lay in the non-constitutional rules of privilege that the courts had developed for judicial and executive officers. ${ }^{45}$

The executive's immunity had begun with Spalding $v$. Vilas, ${ }^{40}$ a suit against the Postmaster General for malicious interference with contract rights by official pronouncements and communications. The Supreme Court held that the defendant enjoyed an absolute immunity so long as he had taken action "having more or less connection with

42. According to the report of the case in $26 \mathrm{~L}$. Ed. 377, 383, "the other defendants, after pleading the same matters set out in Thompson's plea, add [the immunity argument], pertinent to themselves and not to him ...." Cf. 103 U.S. at 177 (sjllabus). 43. 341 U.S. at 378.

44. Cf. Comment, Absolute Privilege as Applied to Intestigalors for Congressional Commitlees, 63 CoLUM. L. REv. 326, 329 (1963).

45. Cf. Barr v. Matteo, 360 U.S. 564, 569 (1959). See also Note, Civil Liability of Subordinate State Officials Under the Federal Givil Rights Acts and the Doctrine of Official Immunity, 44 CALIF. L. REv. 887 (1956); Note, Liability of Public Officers to Suit Under the Civil Rights Acts, 46 Colux. L. REv. 614 (1946).

46. 16 I U.S. 483 (1896). 
the general matters committed by law to his control or supervision"; 47 personal malice toward the plaintiff would be relevant only where the defendant as "head of a Department" had acted "in reference to matters . . . manifestly or palpably beyond his authority . . ." 48 Lower federal courts subsequently applied the Spalding rule to protect the Attorney General, ${ }^{49}$ the Secretary of the Interior, ${ }^{50}$ and the members of the Securities and Exchange Commission ${ }^{61}$ from libel and malicious interference suits. In Barr v. Matteo, ${ }^{52}$ a sharply divided Supreme Court expanded the principle to cover the Acting Director of the Office of Rent Stabilization, but with a sliding test for the scope of the immunity depending on the duties of the protected officer:

[T] he occasions upon which the acts of the head of an executive department will be protected by the privilege are doubtless far broader than in the case of an officer with less sweeping functions. But that is because the higher the post, the broader the range of responsibilities and duties, and the wider the scope of discretion, it entails. It is not the title of his office but the duties with which the particular officer sought to be made to respond in damages is entrusted-the relation of the act complained of to "matters com. mitted by law to his control or supervision," Spalding v. Vilas, ... - which must provide the guide in delineating the scope of the rule which clothes the official acts of the executive officer with immunity from civil defamation suits. ${ }^{53}$

Later decisions in turn extended the Barr rule far down the govern. mental hierarchy to include such functionaries as postal clerks, ${ }^{\text {,1 }}$ road and ground maintenance foremen, ${ }^{65}$ and state race track officials. ${ }^{\circ 0}$ Assistant; conspiracy to monopolize sale of timber); Chavez v. Kelley, 364 F.2d 113 (10th Cir. 1966) (bureau of narcotics local chief; relaying slanderous grand jury information to customs officers); Harmon v. Superior Court, 329 F.2d 154 (9th Cir. 1964) (Superior Court of Los Angeles County, certain judges, the County Sheriff, District Attorncy, County Clerk, Probation Officer, Court Trustee, County Auditor and County Treasurcr general allegation of conspiracy to deprive plaintiff of constitutional rights); Brownficld v. Landon, 307 F.2d 389 (D.C. Cix. 1962) (Air Force Inspector General; slander at meeting called to clear up charges against electric company); Poss v. Lieberman, 290 F.2d 358 (2d Cir. 1962) (claim representative of the United States Department of Health,
} 
Wheeldin $v$. Wheeler ${ }^{57}$ gave the Supreme Court its first opportunity to determine the applicability to legislative employees of the commonlaw immunity recognized for executive employees in Spalding and Barr; but the Court chose to skirt the issue. In the course of deciding that Congress had not created a federal cause of action for a House Un-American Activities Committee employee's service of subpoena allegedly causing the plaintiff to lose his job, Mr. Justice Douglas observed in dictum that the Barr immunity could not apply where the defendant in issuing the subpoena "was not acting sufficiently within the scope of his authority to bring the doctrine into play." sage implied that the doctrine would have come into play had the legislative employee not exceeded his delegated powers. In the course of sidestepping the applicability of the Barr immunity, unfortunately, the Court did not indicate under what circumstances, if any, the Speech or Debate immunity would also have become available.

To be sure, the question was academic if the two immunities immunized alike. But they could not, and they did not. They could not because Congress might always overturn Barr by statute, while Johnson stood as a matter of constitutional construction. And they did not, because by the time of Johnson and Wheeler the two privileges had diverged widely in both the range and character of their application. The Barr rule established an absolute immunity within the outer perimeter of the executive officer's function, including virtually all officers in that branch of government. The Johnson decision, however, not only had reintroduced the subjective motive element to an uncertain degree, but also had left unsettled how far down the legislative hierarchy the protection of the Speech or Debate Clause reached.

Education, and Welfare; libel in confidential report for intemal agenc usc); Ore Gustavsson Contracting Co. v. Floete, 299 F.2d 655 (2d Cir. 1962) (contracting officer of the General Services Agency and his assistant; willful and malicious filing of false reports resulting in cancellation of construction contract); Bershad v. Wood, 290 F.2d 714 (9th Cir. 1961) (Internal Revenue officers; levying on plaintiffs bank deposits); De Levay v. Richmond County School Board, 248 F.2d 340 (4th Cir. 1960) (state school board members; defamation) (alternate holding); Sauber v. Gliedman, 283 F.2d 941 (7th Cir. 1960) (Special Assistant to the Attorney General; malicious and slanderous statements made to press); Preble v. Johnson, 275 F.2d 275 (10th Cir. 1960) (naval enlisted servicemen and civil service employees of Naval Air Technical Training Center; libel made in course of investigating plaintiff's performance of official duties). For cases holding that the acts complained of lay bejond the scope of employment, sec Kelley v. Dunne, 344 F.2d 129 (Ist Cir. 1965) (postal officer; tort liability arising from warrantless search and seizure); Hughes v. Johnson, 305 F.2d 67 (9th Cir. 1962); (federal game wardens; unlawful search of premises over protest by owners and without warrant or arrest); Selico v. Jackson, 201 F. Supp. 475 (S.D. Cal. 1962) (city police officers; unlawful assault).

57. 373 U.S. 647 (1963).

58. Id. at 651 . 
II.

Last May came the most recent Supreme Court discussion of the Clause. Dombrowski v. Eastland ${ }^{59}$ originated in the same series of events that gave rise to the celebrated Dombrowski v. Pfister ${ }^{00}$ decided two years earlier. The petitioners-a Louisiana civil rights organization, Southern Conference Educational Fund (SCEF), and its executive director, Dombrowski-alleged that Senator James Eastland of Mississippi and his Internal Security Subcommittee counsel, J. G. Sourwine, had conspired with Louisiana officials, under color of unconstitutional state laws, to contrive illegal seizures of petitioners' books, records, and membership lists in violation of the Fourth Amendment and to deter petitioners from the exercise of their First Amendment rights. ${ }^{61}$

According to the complaint, in the summer of 1963 Jack Rogers, counsel to the Louisiana Joint Legislative Committee on Un-American Activities, informed Sourwine that the state legislators were planning to get hold of petitioners' records and that he would notify Sourwine as soon as they had them in their possession. ${ }^{22}$ Sometime in August, the state committee decided to obtain the documents under the searchand-seizure provisions of the Louisiana anti-subversive laws rather than through a legislative subpoena. ${ }^{63}$ In mid-September Rogers and Sourwine again discussed the impending raid; ${ }^{64}$ from this conversation, if from anything, arises the inference of a knowing concert of action between the respondents and the state officers. ${ }^{65}$ On October 4, Louisiana authorities seized the entire contents of the SCEF office-a truckload's worth-and arrested Dombrowski. ${ }^{60}$

Later on in the month, a state judge quashed both the search and arrest warrants as not based on probable cause, ${ }^{07}$ and ordered the

59. 387 U.S. 82 (1967).

60. 380 U.S. 479 (1965).

61. A separate action against the state officials is pending in the federal district court for the Eastern District of Louisiana. Petition for Certiorari, Dombrowski v. Eastland, 387 U.S. 82 (1967), at 15-16.

62. Record at 40,71 .

63. Compare the statement of Colonel Alexander, staff director of the Joint Committee (placing the development of the plan to use search warrants rather than subpocnas as early as August 27, 1963), Brief for Petitioners at $6 \mathrm{n.3}$, with that of Rogers (placing the decision-making date in late September), Record at 71, 72.

64. Record at 40, 71 .

65. Sourwine told Eastland of his mid-September talk with Rogers. Record at 40. Petitioners' inference is that Sourwine and Eastland knew of the nature and type of the raid before it occurred, that they concurred in the method, and that they may have encouraged it.

66. Record at 21-25. See also Dombrowski v. Pfister, 380 U.S. at 487 n.4.

67 . Record at 19,20 . The dismissal at the preliminary hearing is unreported. 
seized materials returned to petitioners; ${ }^{68}$ in April, 1965, the Supreme Court responded to petitioners' extraordinary suit to enjoin enforcement of the anti-subversive statute by declaring the law unconstitutional on its face, ${ }^{69}$ and ordered "immediate return of all papers and documents seized."70 Before these developments, however, Rogers telephoned Sourwine on the night of the raids to tell him of the day's events. ${ }^{71}$ Sourwine arrived in New Orleans early the next morning, October 5, with a clutch of United States Senate subpoenas in his briefcase. ${ }^{72}$

Here the tales of the litigants part company. Sourwine claims that the subpoenas were signed in blank by Eastland-a standard operating procedure ${ }^{73}$-and that after examining the seized documents and discussing them with Eastland over the telephone, he filled out the subpoenas to cover all of petitioners' records and served them on Rogers. ${ }^{74}$ The petitioners, on the other hand, intimate that the subpoenas were all filled out by the time Sourwine arrived on the scene, because he, perhaps with Eastland, had prepared them in Washington in anticipation of the raid. ${ }^{i 5}$ The fact that the papers were dated October 4, the day of the raid and the day before Sourwine got to New Orleans, certainly adds a string to petitioners' bow; Sourwine sny's that the New Orleans secretary who typed out the papers made a mistake. ${ }^{76}$ At any rate, the SCEF material passed into federal "possession" on October 5, with Sourwine leaving the materials in the custody of the state police. ${ }^{77}$

On October 25, petitioners moved in state court for return of their property. Rogers defended on the ground that all the materials had

68. The opinion, reproduced in Brief for Petitioners, Appendix B, rested on Mapp v. Ohio, 367 U.S. 643 (1961).

69. 380 U.S. at 494 (declaratory relief granted), 497 (remand to state courts to salvage statute by narrowing construction).

70. Id. at 497.

71. Record at $40,48,73$.

72. Record at 32 .

73. See Brief for Respondents, at 9 n.5.

74. Record at 32,41 .

75. Record at 32, 33; Brief for Petitioners at 10.

76. Record at 33,41 . Sourwine himself has acquired a reputation for mistakes. See, e.g., Sherrill, How to Succeed on the Potomac: Be an Investigator, N.X. Timcs, Oct. 8, $1967, \& 6$ (Magazine), at 146:

Several times Sourwine has carelessly subpoenaed the wrong person, but eren when the mistake became obvious he refused to change it. One witness haled before the Internal Security Subcommittee by error had to fight through the courts for 10 years before he cleared his name. Sourwine testified that he had alled the vitness in good faith on the basis of information received in a letter, but when the defense counsel asked to see the letter, Sourwine replied that he had destrojed it "by" mistake."

77. Record at $41,72$. 
passed to the federal government and were hence unavailable. The defense was the first notice to petitioners that their goods had changed hands some three weeks earlier. Two days after the hearing, on Sunday, October 27, petitioners sued Rogers and other state officers in federal district court to compel return of the documents, and moved for an order to restrain respondents from transferring the records. Judge Ainsworth, upon receiving respondents' assurances that the records would not be disturbed, ordered the case continued over the weekend and the motion returnable on Monday, October 28.78 Petitioners sent a telegram to Eastland to inform him of the Monday hearing. ${ }^{79}$ The Senator then called Sourwine, who had returned to New Orleans for the state proceeding, and, according to the uncontested averments in petitioners' complaint, directed him to get the records out of Louisiana. ${ }^{80}$

In the dead of Sunday night, Sourwine supervised the loading of all the documents into a van graciously lent him by Louisiana officials, and shipped the load across the state line into Mississippi for storage with the clerk of the Chancery Court in Woodville. ${ }^{81}$ The next morning, respondents' attorneys informed the Louisiana federal court that the records had passed beyond its jurisdiction, so that the issue underlying petitioners' request for a temporary restraining order was moot. ${ }^{82}$

In a few days SCEF and Dombrowski brought a Section 1983 civil rights suit against Eastland and Sourwine in the District of Columbia district court for an injunction and $\$ 500,000$ damages, charging them with participation in the initial Louisiana conspiracy. ${ }^{83}$ Judge Holtzoff dismissed the claim for injunctive relief on a separation-of-powers theory, relying on respondents' affidavits that the records had passed into the possession of the legislative subcommittee. ${ }^{84}$ In the damage

78. Record at 28-29.

79. The telegram stated: "Federal Judge Robert Ainsworth has requested your presence in his office 9:30 a.m., October $28 \mathrm{th}$, to discuss an injunction enjoining turning over SCEF and Smith and Waltzer records to Senator Eastland." Record at 54.

80. Complaint, Record at 7, 8; Record at 55 .

81. Complaint, Record at 7, 8; Record at 55, 56, 58 .

82. Record at 29.

83. Petitioners were able to sue the federal officials on an underlying federal con. stitutional claim-here, violation of first and fourteenth amendment rights-only by virtue of the defendants' alleged participation in a state conspiracy. Cf. Wheeldin v. Wheeler, 373 U.S. 647, 652 (1963) (no general federal "under color" statute applicable to federal officials). In effect, the suit was against defendants as private citizens ratlicr than in their capacity as senator and subcommittee counsel. Absent alleged participation by state officers, petitioners could have sued Eastland and Sourwine only on a statebased cause of action, such as trespass.

84. The opinion is reproduced in the Record at 12-15. 
action Judge Sirica granted without opinion respondents' motion for summary judgment accompanied by affidavits denying participation in the conspiracy. ${ }^{85}$

In an opinion rendered three weeks before the Supreme Court's decision in Johnson, the court of appeals affirmed both judgments per curiam..$^{86}$ It denied equitable relief for failure to join the entire subcommittee as an indispensable superior under the rule in Williams $v$. Fanning, ${ }^{8 \tau}$ and because an injunction directed to the defendants alone would be inefficacious. ${ }^{88}$ The damage action gave the court more trouble. What with the razzle-dazzle of document shuffing, the judges understandably thought they "might have considerable difficulty in concluding that there were no disputed issues of fact requiring exploration and resolution by means of a trial." 89 But pursuit of that inquiry was unnecessary, since the record before the district court "contained unchallenged facts of a nature and scope sufficient to give [both] appellees an immunity" under the Speech or Debate Clause. Congress could undoubtedly investigate subversive activities in the United States; the Internal Security Subcommittee, by virtue of its decade-long "active interest in appellants," could validly have authorized Eastland to subpoena the SCEF documents, although in fact it had not; and its subsequent approval of his action operated as a "nunc pro tunc ratification and consequent validation," at least for immunity purposes. $^{91}$ The defendants, in short, came within the Tenney scope of legitimate legislative activity. The court distinguished Wheeldin as a case where the defendant had acted beyond the scope of the authority delegated to him; $;^{22}$ and petitioners' argument that the protection of the legislative immunity doctrine might not extend to Sourwine was disposed of by a fleeting and unilluminating reference to Barr $v$. Matteo.93

85. Brief for Petitioners at 17-18.

86. Dombrowski v. Burbank, 358 F.2d 821 (D.C. Cir. 1966).

87. 332 U.S. 490 (1947)

88. 358 F.2d at 824 (relying on Virginia Ry. v. System Fed'n, 300 U.S. 515 (1937)).

89. 358 F.2d at 824

90. Id.

91. Id. at 825 . The limitation to the immunity context was necessary to avoid petitioners' argument from the contempt prosecution cases that criminal convictions would not stand where underlying subpoenas were invalid for issuance without prior authorization of the full committee. Shelton v. United States, 327 F.2d 601 (D.C. Cir. 1963); cf. United States v. Rumely, 345 U.S. 41, 48 (1953); Brief for Petitioners, Dombrowski v. Eastland, 387 U.S. 82 (1967) at 72 n.64; Petition for Certiorari at 28 n.17. 92. $358 \mathrm{~F} .2 \mathrm{~d}$ at 825 .

93. Id. at 826 n.11. Perhaps the court thought that Barr had overruled, sub silentio, the Kilbourn language denying constitutional immunity to the legislative emplojec. If the court recognized that Barr involved a judge-made rule and Kilboum a constutu- 
Unfortunately, the court's argument discussed only the portion of petitioners' case relating to Sourwine's use of the subpoenas to bring the material within federal possession after the Louisiana seizures; it overlooked petitioners' contention that the appellees had participated in the initial conspiracy to raid the files. ${ }^{94}$ There were two possible explanations for the omission, neither of them satisfactory. The first was that the justification from subsequent ratification applied only to respondents' post-raid conduct, while the Tenney rule protected them for whatever might have gone before. The court could have developed a respectable argument that cooperation with state officers in procuring information is a customary legislative function, and so within the Tenney test for scope of activity; but that was hardly a matter to be decided sub silentio.

The second explanation was that the court regarded the subsequent ratification as immunizing respondents for their activities both before and after the raid. But nobody was suggesting that the subcommittee's subsequent ratification even purported to operate as a nunc pro tunc validation of the defendants' participation in a search and seizure which a state judge had already held unlawful. If the sole basis for respondents' invocation of a Speech or Debate immunity now lay in the subsequent ratification by the subcommittee, the defense of privilege for pre-raid activity should have failed. ${ }^{\circ 5}$

Appellants were arguing, in effect, only for the chance to go agrinst the defendants stripped of their immunity and to show the Section 1983 requisite of actual malice. The court, however, placed the allegation of malice in the wrong hopper, stating the contention as one that "appellees, by acting without prior authorization, acted with a malicious purpose ...."96 That kind of lawsuit, the court said, would be

tional privilege, so that Barr could apply without overruling Kilbourn, it did not so indicate.

94. See Record at $4-7$ for the allegation; the court acknowledged it, $858 \mathrm{~F} .2 \mathrm{~d}$ at 822 , but did not discuss it. See the Supreme Court notation of the omission, 387 U.S. at 89.81.

95. The Wheeldin case should have controlled on the court's theory that without a subsequent ratification defendants would have excceded their authority. Still, the court brushed aside plaintiffs' argument that the defendants' positions with the Subcommittec should be "regarded as incidental and irrelevant to the present suit; and that appellecs [should] be viewed as in the position of any other citizen"; that, said the court, "ignore[d] that the conduct of which appellants complain ... could not have been undertaken had appellees had no official legislative positions and responsibilities." $358 \mathrm{~F} .2 \mathrm{~d}$ at 826. But liability under Section 1983 does not require that the conspirator have the status of a United States Senator or subcommittee counsel; and if the court really meant that only the fact of subsequent ratification saved defendants from liability for their conduct after the raid, then the absence of that ratification should have subjected the defendants to a Wheeldin-type liability qua private citizens for their ultra vires acts before the rald.

96. 358 F.2d at 825 n.9. 
improper, because Tenney "preclude[d] inquiry into appellees' motives to determine the legitimacy of their conduct. . . "0r But even if that statement of petitioners' theory of the case was correct-which it was not-its view of the applicable law was good for only three weeks past the date of decision. Twenty days after the court of appeals had disposed of Dombrowski, the Supreme Court handed down the opinion in Johnson with its language undermining Tenney's flat proscription of inquiry into motive. ${ }^{98}$

The Supreme Court's per curiam disposition of Dombrowskit is hardly calculated to relieve the confusion. To begin with, it lacks so much as a reference to the injunction suit, although that issue was presented in the petition for certiorari, ${ }^{100}$ not excluded in the grant, ${ }^{101}$ and fully treated in the briefs. ${ }^{102}$ On the damage action, the Court notes the failure of the court below to discuss the evidence as it related to respondents' pre-raid activity, ${ }^{103}$ but it does not remand for reconsideration. .04 $^{10}$

The Court holds that, on the present state of the record, the petitioners can go to trial against Sourwine, but not against Eastland. As to the Senator, the justices "agree with the lower courts that petitioners' complaint must be dismissed. The record does not contain evidence of his involvement in any activity that could result in liability." 105 Since the damage action was decided on summary judgment without trial, the only evidentiary deficiency the Court can be speaking of is petitioners' failure to set forth specific facts showing a genuine issue for trial in opposition to respondents' motion with supporting affidavits for summary judgment. That is an eminently proper basis for a grant of summary judgment, but the reasoning implies that petitioners could have gone to trial against Eastland if only they had presented such evidence, and that in turn means that the Speech or

97. Id.

98. See p. 372 supra.

99. Dombrowski v. Eastland, 387 U.S. 82 (1967).

100. Petition for Certiorari at 35-41.

101. 385 U.S. 812 (1966).

102. Brief for Petitioner at 106-12; Brief for Respondents at 41-49. Perhaps the Court thought the issue frivolous or moot.

103. 378 U.S. at 83-84.

104. The Court scrupulously refrains from passing on the legal consequences of the collaboration, if it occurred. See 387 U.S. at 84 . The Court also notes the existence of "controverted evidence," such as the dispute over the date on Sourwinc's subpocmas to Rogers, which it says "affords more than merely colorable substance to petitioners" assertions ...." Id. It carefully declines to consider whether such evidence standing alone would suffice to support a verdict for petitioners or would require a verdict lor respondents.

105. Id. 
Debate immunity did not automatically protect the Senator. Since on a Tenney theory the Clause should shield the Senator from suit regardless of his motives as long as he was acting in behalf of an investigating committee, and thus within the objective scope of his employment, ${ }^{106}$ the theory the Court is now relying on to find the protection potentially unavailable depending on the state of petitioners' evidence becomes crucial in determining how the privilege has narrowed.

The Court says, "It is the purpose and office of the doctrine of legislative immunity, having its roots in the Speech or Debate Clause of the Constitution [citing Kilbourn] . . . , that legislators engaged 'in the sphere of legitimate activity' [citing Tenney] . . . should be protected not only from the consequences of litigation's results but also from the burden of defending themselves." 107 That explanation departs somewhat from the rationale offered only fifteen months earlier in Johnson, where Mr. Justice Harlan had announced that the "predominate thrust" of the Clause was to afford protection from "instigation of criminal charges against critical or disfavored legislators by the executive in a judicial forum ...."108 The difference in the issues presented by the two cases-one a civil suit, the other a criminal prosecution-may explain the sudden shift in rationale, but can hardly justify the switch. The successive analyses look more like ad hoc responses to separate attacks on the privilege than like elements of an overarching, comprehensive theory of the Clause. More importantly, the explanation now tendered for the immunity cannot explain the holding in the case, unless the Court is now implying that Eastland may not have been acting within the Tenney test of scope of employment; for the Court has just finished suggesting that Eastland would have had to face precisely the burden that the Clause is now said to guard against if only the petitioners had proffered some eviclence in response to the motion for summary judgment. The only basis for that finding, though, would be the Senator's improper purpose and malice toward petitioners, since any cooperation with state officials would otherwise be well within his legislative employment, and such consideration of motive was just what Tenney should have excluded from judicial consideration. The Court does not mention Johnson's hesitant endorsement of a modified inspection of motive, although the implicition of the Dombrowski language is that petitioners could have suc-

106. See, e.g., Dombrowski v. Burbank, 358 F.2d 821 (D.C. Cir. 1966).

107. 387 U.S. at 83-84.

108. 383 U.S. at 182 (emphasis added). 
ceeded by showing senatorial mala fides. The result is a privilege whose "outer perimeters" and inner content are both more unsettled now than ever before.

The question of employee immunity fares no better. In explaining why Sourwine must face trial while Eastland gets off, the Court reports it "has held ... that [the constitutional] doctrine is less absolute, although applicable, when applied to officers or employees of a legislative body, rather than to legislators themselves." 103 But the language in the cases the Court refers to for its past "holdings" barely rises to the level of dicta: Tenney had said that the one "deserves greater respect" than the other, ${ }^{110}$ and Wheeldin had only intimated that the common law of Barr $v$. Matteo might apply.111 Dombrowski at least makes it clear that Wheeldin did not exclude application of the constitutional privilege by a process of implication; unfortunately, it is impossible to determine whether Dombrowski itself has now excluded Barr v. Matteo by the same process, included it as a supplement, or subsumed it along with the Speech or Debate immunity in one allencompassing constitutional privilege for employees.

In Dombrowski the difference between legislators and their employees is said to turn on the state of petitioners' evidence. But the evidence tending to show pre-raid conspiratorial participation was more or less the same against both Eastland and Sourwine; ${ }^{112}$ against both, the complaint surely stated a cause of action under Section 1983, and, except for the failure to produce enough evidence to circumvent the immunity bar, it would presumably have entitled the petitioners to carry the factual issues to a jury. The real line-drawing must occur

109. 387 U.S. at 85 . Sourwine reportedly responded to the holding with the complaint: "I thought immunity was like pregnancy-either you were or you weren't. If a Government worker can be harassed for years in court, what good is immunity" The point seems well taken: already Sourwine faces another witness' $\$ 30$-million suit for mistreatment Sherrill, How to Succeed on the Potomac: Be an Investigator, N.Y. Times, Oct. 8, 1967, \& 6 (Magazine), at 146. See N.Y. Times, Oct. 26, 1967, at 35, col. 1, where the most recent legal action against Sourwine is described. The National Conference for New Politics and the Mississippi Freedom Democrats seek $\$ 500,000$ in damages and an injunetion against Sourwine, Eastland, and Benjamin Miandel, research director of the subcommittee. The complaint alleges that two persons "of state, local or Federal law enforcement and/or extra legal agencies" stole the documents from plaintiffs" temporary hotel rooms in Chicago and delievered them to Eastland or Sourwine. Attornejs for the defendants acknowledged that the subcommittee had possession of the documents, but no one would disclose how it came into possession of the missing papers.

110. 341 U.S. at 378.

111. See 373 U.S. at 650-51.

112. The evidence against Sourwine is only somewhat stronger; the misdating of the subpoenas is the only major difference. Still, the Court emphasizes this point, 387 U.S. at 84, perhaps thus disparaging the evidentiary value of the pre-raid telephone calls. The Court is probably correct to dismiss the conversations, because equally plausible inferences of legitimate activity arise from the same circumstances. 
somewhere in the interstices of the expression "less absolute, although applicable." Perhaps the Court is thinking of a graduated distinction analogous to the one established in Barr $v$. Matteo. That raises the question whether the constitutional immunity alone suffices to protect congressional members and officers, or whether the nonconstitutional privilege developed in the executive sphere should carry over to the legislature. And if so, the next question is where the former leaves off and the latter begins.

III.

In basing a general legislative immunity on the constitutional foundation of a broad interpretation of the Speech or Debate Clause, the Supreme Court has lost some of the flexibility it might have retained had it given the Clause a strictly literal reading while supplementing it with a common law standard of the sort fashioned for executive officers. Still, even with the constitutional approach the justices have fixed firmly the principle-vital for continued judicial supervision-that not the dignity of high political office, but the nature of the functions exercised is the touchstone of the constitutional privilege. Within that framework, the courts have managed to reserve a good deal of room for maneuver despite the constraints of constitutional adjudication.

Flexibility is distinguishable from wooliness, however, and not one of the rationales the courts have devised for the immunity has explained the doctrine any more than was necessary to dispose of the case at hand. Maintaining unfettered communications between legislators ${ }^{113}$ gets rid of the libel cases; but standing alone it imposes an unduly restricted scope on the immunity, given the need for communication to constituents and representation before executive agencies.114 A more decisive criticism is that such a narrow theory of the immunity by itself cannot justify other judicial sallies beyond the four walls of the Clause, since securing a free exchange of views among legislators lies well within the power of the constitutional provision even when read literally.

Unfortunately, the rationales the Court has advanced for these latter, more far-ranging forays are inadequate to justify extension of the

113. See, e.g., MicGovern v. Martz, 182 F. Supp. 343, 347 (D.D.C. 1960).

114. The "lobbying" function of congressmen has long been the subject of scholarly commentary. See, e.g., V. O. Key, Polrrics, PARTIEs, ANd Pressure Grours (9d cd. 1952); E. Griffith, Concress: Its Contemporary Role (3d ed. 1961). 
constitutional privilege. First, preserving "legislative peace of mind"115 by sparing senators and representatives the threat of inconvenient trials and personal liability ${ }^{110}$ is surely not the ultimate consideration when private citizens sue. The rationale of sparing members of Congress the rigors of litigation ignores that the Department of Justice provides counsel gratis ${ }^{117}$ - so that the demands of the legal process amount to little more than helping prepare affidavits to accompany the motions for summary judgment, and perhaps testifying if the case reaches trial. And the theory that money judgments must be avoided similarly overlooks the availability of private tort insurance or public indemnification. ${ }^{118}$

Second, the need to restrain executive intimidation and harassment $t^{119}$ cannot be the true explanation for the "predominate thrust" of the privilege ${ }^{120}$ even in the criminal cases, for that argument would lead-as it has not yet-to invalidation of the broad conflict-of-interest and defrauding - the - United States statutes ${ }^{101}$ enforced on occasion against errant congressmen. ${ }^{122}$

Still, the explanations when taken together perhaps do add up to a fairly coherent view of the scope of the privilege. The central feature underlying each of the rationales, but left more or less unexplored in the opinions, is the prime requirement for any judicially-created immunity doctrine: the courts' own interest in reconciling control of aberrant conduct by individual legislators or staff members with a

115. McGovern v. Martz, 182 F. Supp. 343, 346 (D.D.C. 1960).

116. See, e.g., Gregoire v. Biddle, 177 F.2d 579, 581 (2d Cir. 1949); Coffin v. Coffin, 4 Mass. 1, 27 (1808), quoted approvingly, Kilbourn v. Thompson, 103 U.S. 168, 203 (1891).

117. 2 U.S.C. \& 118 (1964).

118. There are, perhaps, cogent objections to any judicial decision that explicitly reasons along such lines; but they originate more in political-question than in scope-ofimmunity considerations. See p. 386 infra. Several commentators have urged the expansion of the Federal Tort Claims Act, 28 U.S.C. $\$ 2674$ (1964), to cover legislators and their subordinates. See, e.g., Yankwich, The Immunity of Congressional Speech-Its Origin, Meaning and Scope, 99 U. PA. L. REv. 960 (1951); Handler \& Klein, The Defense of Privilege in Defamation Suits Against Goternment Executice Officials, 74 HARv. L. REV. 44, 76 (1960). See also Lovell, Scope of the Legislative Intestigational Power and Redress for its Abuse, 8 HAstnas L.J. 276 (1957).

119. E.g., United States v. Johnson, 383 U.S. I69, 181 (1966); Tenney v. Brandhove, 341 U.S. 367,378 (1951); Kilbourn v. Thompson, 103 U.S. 168, 201.02 (1881).

120. The phrase is from United States v. Johnson, 383 U.S. 169, 182 (1960).

121. See note 36 supra; on the generality of the latter statute, see Goldstein, Conspiracy to Defraud the United States, 68 YALE L.J. 405 (1959).

122. E.g., United States v. Johnson, 383 U.S. 169 (1960); Mray v. United States, 175 F.2d 994, 1006 (D.C. Cir. 1949) (bribery). But see United States v. Dictrich, 120 F. 604 (8th Cir. 1904).

Another occasionally mentioned rationale for the Clause turns on a conspincy theory of litigation. Representatives Halleck and MCCormack have expressed their concern that without the immunity legislators might be subjected to a concert of litigious action designed to tie up the entire Congress. See 99 CoNG. Rrc. 2356 et seq. (1953). 
healthy respect for a coordinate branch of the federal government. This is close to the formal political-question issue, ${ }^{123}$ and, not surprisingly, it appears all through the cases, although usually in the guise of a more "classical" separation-of-powers rationale. The logical product of the continuing judicial concern to respect the proper bounds of legislative authority, while yet restraining its exercise,-and the manifestation of the persistent pressure on the judges to broaden the reach of the immunity-is a scope-of-employment doctrine.

That leaves the courts with the job of vindicating genuine private grievance while still preserving legislative discretion. ${ }^{124}$ One solution is a slight restriction of the objective scope-of-employment immunity along the subjective examination-of-purpose lines hinted at in Johnson and Dombrowski. By this analysis, an aggrieved private party should be allowed to proceed against a congressman and his employees wherever he can state a cause of action for tortious conduct of a malicious character, except a speech or debate in the chamber. ${ }^{125}$ Complete

123. See generally Scharpf, Judicial Review and the Political Question: A Functional Analysis, 75 YALE L.J. 517 (1966). In the case, however rare, where affirmation of the lower court's decision on the merits seems indefensible given the shocking nature of the defendant's conduct, but intervention in favor of plaintiff would result in a considerable limitation on the government's freedom of action, the appellate court may resort to the political-question doctrine to avoid having to make a direct choice. $I d$. at 580.81 .

124. The same problem has arisen in the context of criminal prosecutions for failure to answer questions before congressional investigating committees. See 2 U.S.C. \& 192 (1964). In Watkins v. United States, 354 U.S. 178 (1957), the Court reviewcd a conviction for contempt of Congress arising from defendant's refusal to make certain disclosures which he claimed were beyond the authority of the committee to demand. The Government asked the Court to affirm the conviction if there were any legislative purposc which might have been furthered by the kind of disclosures sought; that is, if congress were acting within the range of its power (liberally construed). In far-reaching dicta, the Court rejected the Government's view; because the Bill of Rights applies to investigations as to all forms of governmental action, Congress must not cross the strict limits of its authority. After an initial retreat from the broad language of Watkins, e.g, Barenblatt v. United States, 360 U.S. 109 (1959) (balancing): Wilkinson v. United States, 365 U.S. 399 (1961); Braden v. United States, 365 U.S. 431 (1961), the Court has returned to a rigorous supervision of the procedural niceties: a subpoena issued without prior committee authorization, Shelton v. United States, 827 F.2d 601 (D.C. Cir. 1969), and a departure from the committee's own rules, Yellin v. United States, 374 U.S. 109 (1963), both vitiate a contempt conviction; furthermore, to satisfy the requirements of the contempt statute, 2 U.S.C. $\& 192$ (1964), the grand-jury indictment must specify the subject matter to which the underlying questions were pertinent, Russell $v$. United States, 369 U.S. 749 (1962), and the government at the trial must show pertinency beyond a reasonable doubt, Deutch y. United States, 367 U.S. 456 (1961).

It is not surprising that the Court sets different limits when it revicws the conduct of congressmen in cases where they are defendants. There the issue of the scope of legislative power is a sword in the hands of the private party, not a shield to him by way of defense to a criminal prosecution. The dangers inherent in a clash between the judiciary and the legislative branches are real enough where the Congressman mercly looks on at the loss of a criminal prosecution he has instigated, see W. Murriy, Concres AND THE COURT (1962) (Congressional reaction to Watkins and other decisions); they become all the more alarming where the legislator stands open to injunctive restraint
and financial liability.

125. The cause of action will almost invariably be state-based, since there is no 
protection of verbal expression within the halls of Congxess is the least the clear words of the Clause require, and is consistent with the past decisions. ${ }^{126}$

The proposed test does threaten an increase in litigation against representatives, but the increase is limited to cases where the offense charged is an intentional wrong. The limited vulnerability can be analogized to the boundaries the Court has set for the citizen's right to criticize his public officials. ${ }^{127}$ The comparison has more to recommend itself than mere surface symmetry; the disparity between the absolute immunity which the congressman currently enjoys and the lesser privilege which the New York Times rule ${ }^{198}$ confers on his private critics may well "sanctify the powerful and silence debate. ... [I]t will take a brave person to criticize government officials knowing that in reply they may libel him with immunity in the name of defending the agency and their own position."120 Moreover, the new test for legislative immunity will permit an aggrieved private party redress against conduct that no rationale for the constitutional privilege purports to justify: the exercise of public power with intent to inflict injury on private citizens or with reckless disregard for their interests.

general federal "under color" statute applicable to federal officials. Wheeldin v. Whecler, 373 U.S. 647,652 (1963). The suit against Eastland and Sourvine based on underlying federal constitutional claims was possible only because of the defendants' alleged participation in a state conspiracy; otherwise, the petitioners would have had to find a Louisiana cause of action. The involvement of first and fourteenth amendment rights in the case arose only because of a quirk in the factual circumstances of the case-an in the case arose only buficient to support a Section 1983 cause of action. See note 83 alleged state conspen, the presentation of federal constitutional claims against congress. men and their employees can arise only under unusual conditions, it would be unwise to distinguish, for purposes of defining the scope of the legislative immunity, between such constitutional claims on the one hand, and mere statutory or common law claims on the other.

126. Even here, though, the Court could reinstate the pertinency requirement it first suggested in Kilboum. See p. 368 supra. Only Cochran v. Couzens, 42 F.2d 783 (D.C. Cir. 1930), has purported to repudiate the rule that speech to be protected should have some relevance to the congressman's business. See 1 F. HARPER \& F. JAsies, THE LAw OF TORTS 427-29 (1956).

The temptation to tag libel as non-speech and therefore outside the immunity, although appealing in other areas of constitutional law, Beaubarnais v. Illinois, $343 \mathrm{UUS}$. 250 (1952) (group libel); of. Ginzburg v. United States, 383 U.S. 463 (1960), has not jet suggested itself here and should not be yielded to.

127. See New York Times Co. v. Sullivan, 376 U.S. 254 (1964) ("actual malice" test in libel suits brought by public officials).

128. See note 127 supra.

129. Barr v. Matteo, 360 U.S. 564, 584-85 (1959) (dissenting opinion of Warren, C.J.). The remarks of the Chief Justice were addressed, of course, to the executise immunity that the majority was propounding in the case, and they came before the decision in New York Times. But the disparity problem exists as well for legislators as for administrators, and the "actual malice" rule in New York Times can redress the imbalance only partially, so long as the members of Congress retain a truly absolute immunity. 
A plaintiff who can demonstrate such an abuse of the public trust as that alleged in Dombrowski should be allowed his day in court.

The new rule should contain the further limitation that the plaintiff must have evidence of the defendant's malice before the trial begins-evidence capable of satisfying the strict requirements of the Federal Rules in response to a motion for summary judgment. ${ }^{130}$ Nothing prevents the justices from protecting the still-relevant constitutional immunity from the vagaries of jury decisions by raising the standard the trial court must apply to determine whether the evidence is sufficient to present a question for the jury. ${ }^{131}$ The evidentiary re. striction addresses itself to the theme of avoiding litigation first raised in Kilbourn and reiterated in Dombrowski, but it also serves the judicial interest in curtailing the number of cases presenting the sensitive questions which can arise when congressmen are subjected to the judiciary. ${ }^{132}$

The Barr notion of a scope of immunity varying with the importance of the office held is relevant to the legislative employee problem. ${ }^{133}$ This element of $\mathrm{Barr}$ can be viewed as another application of the essentially political-question philosophy that judicial supervision

130. FED. R. Giv. P. 56(e).

The absence of sophisticated pre-trial litigation-ending devices may have been signiflcant in the old Kilbourm times, but present-day arguments based on the inconvenience of litigation to legislators are less persuasive. See Note, Absolute Immunity: Too Broad a Protection for the "Public Interest"? 10 STAN, L. REv. 589, 593.94 (1958).

131. Cf. Jackson v. Denno, 378 U.S. 368, 378 (1964) (coerced confession) (citing approvingly Massachusetts procedure "under which the jury passes on [the question of] voluntariness only after the judge has fully and independently resolved the issuc against the accused"); Crowell v. Benson, 285 U.S. 22 (1982) (jurisdictional fact), cited (to demonstrate its continued vitality) in Jacobellis v. Ohio, 378 U.S. 184, 190 n.6 (1964) (concurring opinion of Brennan, J.); Ohio Valley Water Co. v. Ben Avon Borough, 253 U.S. 287 (1921) (constitutional fact).

132. In reviewing criminal contempt prosecutions for refusals to answer questiong, the Court has eschewed considerations of motive wherever the justices could discern an independent valid legislative purpose-but then have looked into motive anyway. See Wilkinson v. United States, 365 U.S. 399, 411 (1961); Barenblatt v. United States, 360 U.S. 109, 133, 134 (1959). Cf. Tenney v. Brandhove, 341 U.S. 367, 388 (1951) (dissenting opinion of Douglas, J.): "[W] individual the whole weight of government for an illegal or corrupt purpose, the reason for the immunity ends." Perhaps more correctly, one of the reasons ends-encouragement of free inquiry and action; another-avoidance of litigation-is just beginning.

One possible indicator of malice could be the extent to which the legislator has failed to restrain himself in the methods he chooses to acquire desircd inforiantion or publicize matters he thinks the public should know about. A major deviation from the least means available for achieving the legislative objective, whatever it may be, is hardly consistent with a congressman's surprised innocence. The absence, up to now, of any semblance of judicial supervision over investigatory tactics has cncouraged a wholesale delegation by congressmen of virtually unchecked power to their staff assistants. See Sherrill, How to Succeed on the Potomac: Be an Investigator, N.Y. Timcs, Oct. 8, 1967, \& 6 (Magazine), at 146.

133. See p. 374 supra. 
of the action of a coordinate branch should decline as the function exercised stands higher in the governmental hierarchy, and so the relevance of the case to the congressional-staff question is not surprising. ${ }^{134}$

But Barr also argues against adoption of the proposed restricted scope of legislative privilege, since it accords members of the executive department an absolute immunity that the proposed legislative standard will deny. Still, the courts should hesitate before extending the absolute-immunity aspect of Barr from the executive to the legislative context. ${ }^{135}$ The Barr rule stands as a matter of general law, and as such it can always be overridden by act of Congress; it is a judiciallyfashioned rule of privilege that, although perhaps unduly broad in its protection of government officers and unduly neglectful of the need to compensate private hurt, can be justified in part by the relative availability of popular reversal through the legislature. The Speech or Debate immunity, on the other hand, arises from the Constitution, and so can be modified, once determined by the courts, only through the cumbersome amendment procedure or by judicial self-reversal; a correspondingly higher obligation rests on the judges to fashion at the outset a rule more sensitive to all interests at stake without recourse to the responsibility-shifting philosophy that an initial misstep by the courts will find ultimate correction in the political process.

134. Application of the Barr sliding test to Senate committec counsel could lead to a significant curtailment of their range of activity. For a description of their virtually unlimited power, see Sherrill, supra note 132.

135. There are other ways to dispose of Barr. One is that the case was incorrectly decided and ought to be overruled. The Barr Court split 5-4, and three justices would have preferred only a qualified immunity. 360 U.S. 564, 584-85 (1959) (dissenting opinion of Warren, C.J. \& Douglas, J.); id. at 589 (dissenting opinion of Brennan, J., citing with approval 2 F. HARPER \& F. JAMIES, THE LAW OF TORTS 1645 (1956)). Second, even if it is too late in the day to undo Barr, the case ought to be distinguished. A possible difference is that plaintiffs there were also public employees, so that the absolute immunity conferred on the defendant might be confined to "assumption of risk" situations. A third disposition of Barr may lie in the differing nature of the executive and legislative function. See, e.g., Comment, Absolute Privilege as Applied to Investigators for Congressional Committees, 63 Colvas. L. Rev. 326, 329 n.30 (1963), although arguments based on discretion necessary to performance of function seem equally applicable to both cases. For an intimation that lower courts may have found Barr too much to take, see kelley v. Dunne, 344 F.2d 129 (1st Cir. 1965). 